\title{
IMMEDIATE RECIPROCAL CHANGES AT ADJACENT LEVEL FOLLOWING SINGLE-LEVEL ALIF
}

\author{
ALTERAÇÕES RECÍPROCAS IMEDIATAS DO NÍVEL ADJACENTE APÓS ALIF MONOSSEGMENTAR \\ ALTERACIONES RECÍPROCAS INMEDIATAS DE NIVEL ADYACENTE DESPUÉS \\ DE ALIF MONOSEGMENTARIA
}

Enrique Vargas Uribe ${ }^{1}$, Rodrigo Amaral ${ }^{1}$, Luis Marchi ${ }^{1}$, Rubens Jensen ${ }^{1}$, Leonardo Oliveira ${ }^{1}$, Fernanda Fortti ${ }^{1}$, Etevaldo Coutinho ${ }^{1}$, Luiz Pimenta ${ }^{1}{ }^{2}$

\begin{abstract}
Objective: To assess the segmental sagittal parameters and the adjacent mobile segment after interbody fusion by anterior approach in single-level L5-S1. Methods: Retrospective study. Inclusion: Interbody fusion by anterior approach (10\%15 angle), due to DDD, low-grade spondylolisthesis and/or stenosis without prior lumbar fusion. Thirty-five cases were included (25 women; mean age $47 \pm 15$ years). Analysis of lumbar radiographs were performed preoperatively and 3 months after surgery. The following parameters were evaluated: lumbar Iordosis; segmental lordosis L4-L5 and L5-S1; sacral and L5 slope. Two independent evaluators made the measurements. Student's t test was used. Results: There was correction of lordosis at the L5-S1 level, from an average of $19^{\circ}$ prior to surgery to $28^{\circ}$ three months after surgery $(p<0.001)$. It was observed reduction of the L4-L5 angle from $17^{\circ}$ to $14^{\circ}(p<0.001)$. Moreover, there was a small, but statistically significant, reduction of $L 5$ inclination from $17^{\circ}$ to $13^{\circ}(p=0.007)$ and increase in the sacral slope from $37^{\circ}$ to $40^{\circ}(p=0.002)$. The change of total lumbar lordosis was not significant: $52^{\circ}$ versus $53^{\circ}(p=0.461)$. Before surgical correction, lordosis of the L5-S1 level contributed, on average, $37 \%$ of lumbar lordosis, and after, $54 \%(p<0.001)$. The L4-L5 level accounted for $34 \%$ and decreased to $24 \%$ ( $<<0.001)$. Conclusion: In the group studied, it was observed a decrease in lordosis of the adjacent mobile level following the treatment of the degenerate level by anterior interbody fusion and concomitant increase in lordosis.
\end{abstract}

Keywords: Spine; Spinal fusion; Lordosis; Lumbosacral region; Intervertebral disc.

\section{RESUMO}

Objetivos: Avaliar os parâmetros sagitais segmentares e do segmento móvel adjacente após fusão intersomática por via anterior em nível único L5-S1. Métodos: Estudo retrospectivo. Inclusão: Fusão intersomática por via anterior (com espaçador de 10\%15 de angulação), em decorrência de DDD, espondilolistese de baixo grau e/ou estenose, sem artrodese lombar prévia. Foram incluídos 35 casos (25 mulheres; média de idade $47 \pm 15$ anos). Foram realizadas análises de radiografias lombares no pré-operatório e 3 meses após a cirurgia. Avaliaram-se os seguintes parâmetros: Iordose lombar; lordose segmentar L4-L5 e L5-S1; inclinação sacral e de L5. Dois avaliadores independentes fizeram as medidas. Foi utilizado o teste $t$ de Student. Resultados: Houve correção da lordose no nível L5-S1, com média de $19^{\circ}$ no pré-operatório e de $28^{\circ}$ três

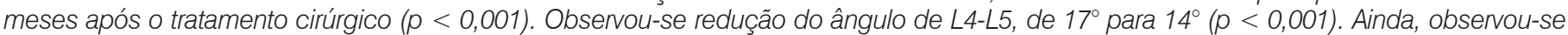
pequena, porém, estatisticamente significante, redução da inclinação de $L 5$, de $17^{\circ}$ para $13^{\circ}$ ( $p=0,007$ ), e aumento da inclinação sacral de $37^{\circ}$ para $40^{\circ}(p=0,002)$. A alteração da lordose lombar total não foi significante: de $52^{\circ}$ para $53^{\circ}(p=0,461)$. Antes da correção cirúrgica, a lordose do nível L5-S1 contribuía, em média, com 37\% da lordose lombar, e após, com 54\% (p < 0,001). Já o nível L4-L5 contribuía com 34\% e diminuiu para 24\% ( $p$ < 0,001). Conclusão: No grupo estudado, foi possível observar a diminuição da lordose do nível móvel adjacente após tratamento de nível degenerado por meio de fusão intersomática anterior e aumento concomitante de lordose.

Descritores: Coluna vertebral; Fusão vertebral; Lordose; Região lombossacral; Disco intervertebral.

\section{RESUMEN}

Objetivo: Evaluar los parámetros sagitales segmentarios y del segmento móvil adyacente después de fusión intersomática por vía anterior en nivel único L5-S1. Métodos: Estudio retrospectivo. Inclusión: Fusión intersomática por vía anterior (con separador de $10^{\circ} / 15^{\circ}$ de angulación), como consecuencia de DDD, espondilolistesis de grado bajo y/o estenosis, sin fusión lumbar previa. Fueron incluidos 35 casos (25 mujeres, promedio de edad $47 \pm 15$ años). Fueron realizados análisis de radiografías lumbares en el preoperatorio y 3 meses después de la cirugía. Se evaluaron los siguientes parámetros: Iordosis lumbar; Iordosis segmentaria L4-L5 y L5-S1; inclinación sacral y de L5. Dos evaluadores independientes hicieron las medidas. Fue utilizado el test t de Student. Resultados: Hubo corrección de la lordosis en el nivel L5-S1, con promedio de $19^{\circ}$ en el preoperatorio y de $28^{\circ}$ tres meses después del tratamiento quirúrgico $(p<0,001)$. Se observó reducción del ángulo de $L 4-L 5$, de $17^{\circ}$ para $14^{\circ}$ ( $p<0,001$ ). Además, se observó pequeña, aunque estadísticamente significativa reducción de la inclinación de $L 5$, de $17^{\circ}$ para $13^{\circ}(p=0,007)$ y aumento de la inclinación sacral de $37^{\circ}$ para $40^{\circ}(p=0,002)$. La alteración de la lordosis lumbar total no fue significativa: $52^{\circ}$ para $53^{\circ}(p=0,461)$. Antes de la corrección quirúrgica, la lordosis del nivel L5-S1 contribuía, promedio, con 37\% de la lordosis lumbar, y después, con 54\% ( $p$ < 0,001). Ya el nivel L4-L5 contribuía con 34\% y disminuyó para 24\% ( $p$ < 0,001). Conclusión: En el grupo estudiado, fue posible observar la disminución de la lordosis del nivel móvil adyacente después del tratamiento de nivel degenerado por medio de fusión intersomática anterior y aumento concomitante de lordosis.

Descriptores: Columna vertebral; Fusión vertebral; Lordosis; Región lumbosacra; Disco intervertebral.

1. Instituto de Patologia da Coluna (IPC), São Paulo, SP, Brazil

2. University of California San Diego - UCSD, San Diego, CA, USA

Study conducted at the Instituto de Patologia da Coluna (IPC), São Paulo, SP. Brazil.

Correspondence: Luis Marchi, Rua Vergueiro, 1421, cj 305, 04101-000, São Paulo, SP, Brazil. marchi@ patologiadacoluna.com.br, 


\section{INTRODUCTION}

Diseases of the spine with degenerative intervertebral disc components tend to reduce the curvature in lordosis. Compensatory mechanisms are created, to maintain regional and global sagittal alignment of the spine. However, these alterations usually involve pain, loss of function, and acceleration of the degenerative cascade. ${ }^{1}$

The compensation mechanisms involve modification of the sagittal curves of the spine and retroversion of the pelvis, in addition to flexion of the knee. Among the sagittal modifications of the spine is an increase in lordosis in the mobile levels adjacent to a vertebral segment with a loss of lordosis, which may be iatrogenic, or the result of the degenerative process, and may be associated with disease at the adjacent level.,2,3

Given that the spontaneous correction of this adjacent compensation mechanism is not well described, the objective of this study is to assess the short-term changes to the regional sagittal parameters and the adjacent mobile segment, following interbody fusion and restoration of segmental lordosis for isolated discopathy of L5-S1.

\section{METHODS}

A retrospective observational study approved by the Institutional Review Board (CAAE 48112515.2.0000.5511). The inclusion criteria were: indication of surgical treatment at a single level in L5-S1 as a result of degenerative disc disease (DDD defined in this work as Pfirrmann ${ }^{4}$ grade IV or $V$ and the presence of Modic changes ${ }^{5}$ ), low grade spondylolisthesis and/or stenosis in the presence of instability; indication of lumbar interbody arthrodesis by the anterior approach only (without supplemental pedicle screws); anterior lumbar interbody fusion (ALIF) using an autoblocking titanium cage as an interbody spacer, with a $10-15^{\circ}$ angle of lordosis (FUSIMAX Cage on Cage/Sistema SAGA, MDT Implantes/LAS Brasil, São Paulo); the existence of preoperative $x$-rays and $x$-rays taken after 3 months of postoperative follow-up. The exclusion criteria were: no presentation of an extruded herniated disc at the level to be treated; no presentation of arthrodesis/arthroplasty prior to the ALIF in any lumbar level. This retrospective analysis assessed 90 cases that underwent interbody fusion at level L5-S1 at the same center and, in accordance with the inclusion/exclusion criteria, 35 cases were selected for inclusion. In this group of 25 women and 10 men, the average was 47 years of age. 24 cases had been diagnosed with DDD with severe degenerative alterations and 11 with low grade spondylolisthesis.

The radiological parameters were measured in neutral lateral orthostatic radiographs (Figure 1) taken preoperatively and after 3 months of postoperative follow-up. The following parameters were evaluated: lumbar lordosis (from the plateau above L1 to the plateau above S1); lordosis of the L5-S1 and L4-L5 disc space (the angle between the cranial and caudal vertebral plateaus in relation to the intervertebral disc of reference); segmental lordosis of L5-S1 and L4-L5 (the angle between the vertebral plateaus above the vertebrae adjacent to the vertebral disc of reference); L5 inclination and sacral inclination (angle between the upper plateau of the vertebra and a horizontal line parallel to the ground. Two independent evaluators took the measurements. The averages of the values were used, but if they differed by more than $5^{\circ}$, the measurements were retaken.

The PSAW Statistics 18 program was used for statistical analysis. To test the differences between the two groups the Student's t-test was used and the Pearson coefficient was used to correlate the two groups of measurements. Results with $p$-values less than 0.05 were considered to be statistically significant.

\section{RESULTS}

The results of the radiological measurements are summarized in Table 1.

The average lordosis values of the pathological level, L5-S1, and of the adjacent cranial level, L4-L5, were equal $\left(19^{\circ} \pm 8^{\circ}\right.$ versus $17^{\circ} \pm 6^{\circ}$, respectively; $\left.p=0.0880\right)$ in the preoperative analysis. Even
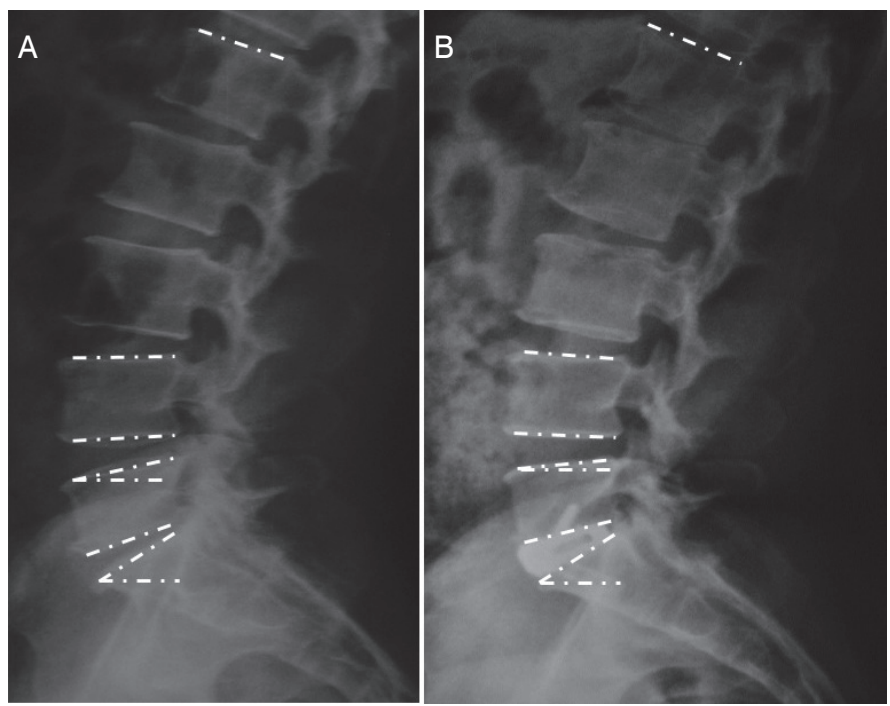

Figure 1. Case example with baselines for measurements. (A) Preoperative radiograph and $(\mathrm{B})$ radiograph 3 months following surgery. The white dashed lines show the determination of the planes (from top to bottom: upper plateau of $L 1$, upper plateau of $L 4$, lower plateau of $L 4$, upper plateau of $L 5$, horizontal plane, lower plateau of L5, upper plateau of S1, and horizontal plane) for the determination of the angles described in the Methods section.

Table 1. Regional changes following ALIF L5S1.

\begin{tabular}{|c|c|c|c|c|c|}
\hline & Pre-op & 3 months & $\mathrm{p}$-value ${ }^{\mathrm{a}}$ & $p$-value ${ }^{b}$ & $p$-value ${ }^{c}$ \\
\hline Segment L5-S1 & $19^{\circ} \pm 8^{\circ}$ & $28^{\circ} \pm 5^{\circ}$ & $<0.001^{*}$ & \multirow{2}{*}{0.091} & \multirow{2}{*}{$<0.001^{*}$} \\
\hline Segment L4-L5 & $17^{\circ} \pm 6^{\circ}$ & $14^{\circ} \pm 5^{\circ}$ & $<0.001^{*}$ & & \\
\hline Disc L5-S1 & $10^{\circ} \pm 7^{\circ}$ & $18^{\circ} \pm 4^{\circ}$ & $<0.001^{*}$ & \multirow{2}{*}{$0.024^{*}$} & \multirow{2}{*}{$<0.001 *$} \\
\hline Disc L4-L5 & $12^{\circ} \pm 4^{\circ}$ & $9^{\circ} \pm 3^{\circ}$ & $<0.001^{*}$ & & \\
\hline Lumbar lordosis & $52^{\circ} \pm 10^{\circ}$ & $53^{\circ} \pm 12^{\circ}$ & 0.461 & - & - \\
\hline Inclination of L5 & $17^{\circ} \pm 9^{\circ}$ & $13^{\circ} \pm 9^{\circ}$ & $0.007^{*}$ & - & - \\
\hline Sacral Inclination & $37^{\circ} \pm 9^{\circ}$ & $40^{\circ} \pm 9^{\circ}$ & $0.002 *$ & - & - \\
\hline
\end{tabular}

Data shown as Mean \pm Standard Deviation. * statistically significant. (a) Pre-op versus 3 months. (b) Pre-op versus Pre-op. (c) 3 months versus 3 months.

though the total change in lumbar lordosis after the fusion of L5-S1 was not significant $(p=0.461)$, the results show that there was an increase in segmental lordosis of L5-S1 of $9^{\circ}$, starting at $19^{\circ}$ and reaching $28^{\circ}(\mathrm{p}<0.001)$. We observed a reduction of the average angle of $\mathrm{L} 4-\mathrm{L} 5$, from $17^{\circ}$ before fusion to $14^{\circ}$ after fusion $(p<0.001)$. Figure 2 shows a case example.

Other values that underwent statistically significant changes were sacral inclination, $37^{\circ}$ versus $40^{\circ}(p=002)$, and inclination of $\mathrm{L} 5$ from $17^{\circ}$ to $13^{\circ}(p=007)$. The distributions of the sagittal correction in the caudal (change in sacral inclination) and cranial (change in the inclination of vertebra L5) directions were not statistically different $(p=0.470)$.

The correlation between the difference (3 months $x$ preoperative) in the angulation of disc L5-S1 and the difference (3 months $x$ preoperative) in the angulation of disc L4-L5 is shown in Figure 3. The correlation was negative and statistically significant $(p<0.001)$, with a coefficient of determination $\left(R^{2}\right)$ of -0.357 and a Pearson correlation coefficient $(\rho)$ equal to -0.597

To assess the distribution of lumbar lordosis among the distal levels before and after fusion, we calculated the percentage of contribution of the segmental lordosis of L4-L5 and L5-S1 to global lumbar lordosis, shown in Table 2. It was shown that in the preope- 
rative period the contribution was statistically the same $34 \%$ and $37 \%$, respectively; $p=0.167$ ). At the three month point, following placement of the lordotic interbody spacer, the contribution of segment L5-S1 increased $(p<0.001)$ and the contribution of segment L4-L5 decreased $(p<0.001)$.

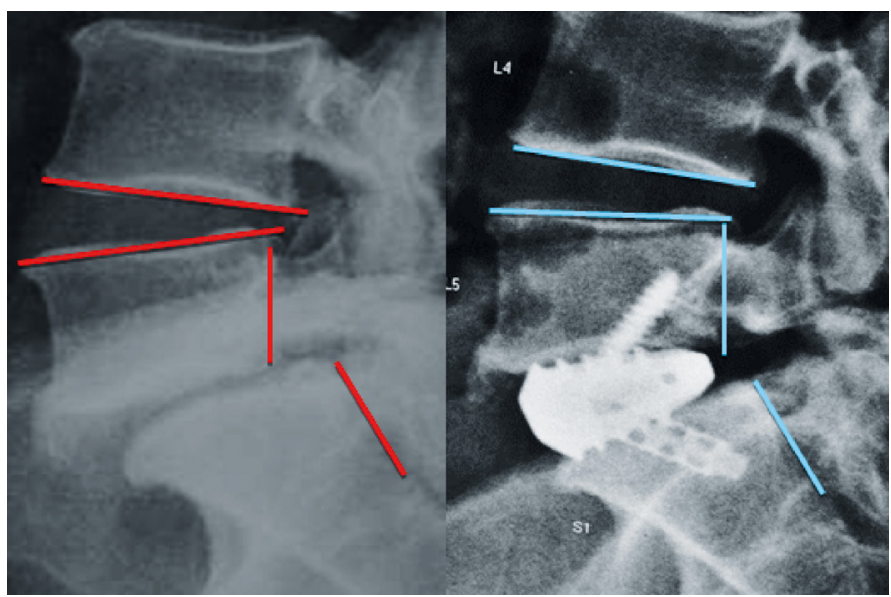

Figure 2. Reduction of compensatory hyperlordosis of L4-L5 following ALIF of L5-S1. Neutral lateral orthostatic x-rays before and three months after interbody arthrodesis.

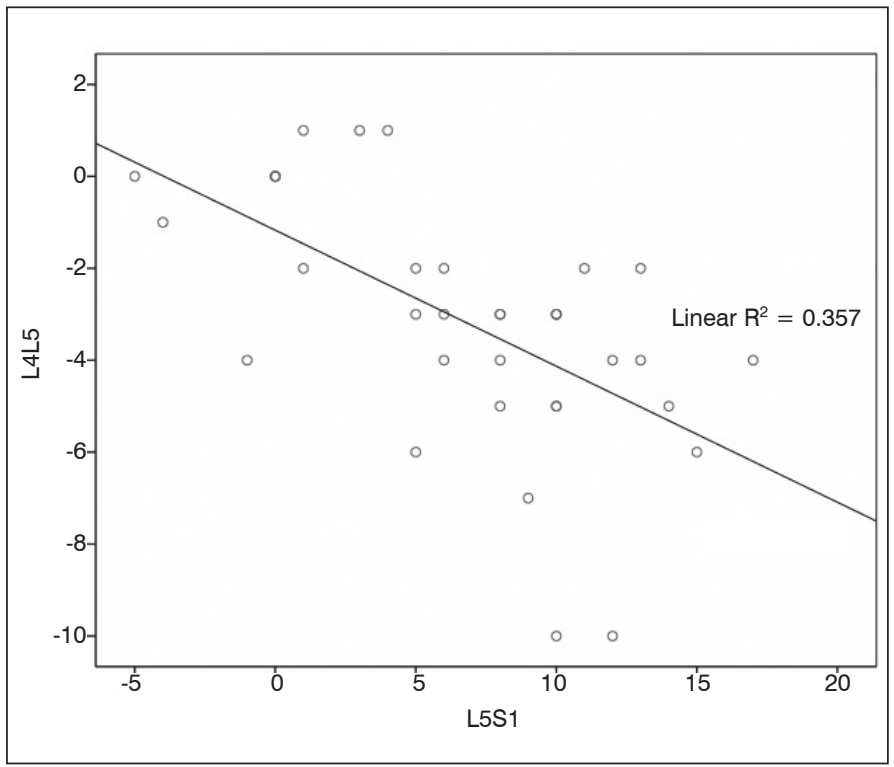

Figure 3. Relationship between lordosis gain in the L5-S1 disc space and lordosis loss in L4-L5. The linear regression shows a significant negative correlation $\left(R^{2}=0.357 ; p<0.001\right)$ between the difference ( 3 months $x$ preoperative) of the angulation of the disc L5-S1 and of disc L4-L5 ( $\rho=-0.597)$.

Table 2. Contribution to lumbar lordosis by specific level.

\begin{tabular}{c|c|c|c|c|c}
\hline & Pre-op & $\mathbf{3}$ months & $\mathbf{p}$-value $^{\mathbf{a}}$ & p-value $^{\mathrm{b}}$ & p-value $^{\mathbf{c}}$ \\
\hline $\begin{array}{c}\text { Segment } \\
\text { L5-S1 }\end{array}$ & $37 \% \pm 14 \%$ & $54 \% \pm 11 \%$ & $<0.001^{*}$ & 0.178 & \\
\hline $\begin{array}{c}\text { Segment } \\
\text { L4-L5 }\end{array}$ & $34 \% \pm 12 \%$ & $24 \% \pm 8 \%$ & $<0.001^{*}$ & & $<0.001^{*}$ \\
\hline Disc L5-S1 & $17 \% \pm 13 \%$ & $32 \% \pm 10 \%$ & $<0.001^{*}$ & $0.018^{*}$ & \\
\hline Disc L4-L5 & $22 \% \pm 8 \%$ & $16 \% \pm 7 \%$ & $<0 ., 001^{*}$ & & $<0.001^{*}$ \\
\hline
\end{tabular}

Percentage of total lumbar lordosis (L1-S1). Data displayed as Average \pm Standard Deviation. *statistically significant. (a) Pre-op versus 3 months (b) Pre-op versus Pre-op. (c) 3 months versus 3 months.

\section{DISCUSSION}

Reciprocal change adjacent to a level with degeneration is a recent theme, and we have not yet identified the description of the short term behavior of the adjacent mobile level following restoration of the space and of the disc angulation via interbody arthrodesis. The main objective of this study was to confirm whether changes occur in the sagittal positioning of the mobile level above an anterior approach interbody fusion in the short term.

The key findings of this work show that following an increase in the angulation of L5-S1, several regional changes occur: an increase in the lordosis of L4-L5, a slight reduction in the vertebral inclination of L5 (which is usually inclined downwards), and an increase in sacral inclination.

The normal angle of global lumbar lordosis is generally between 20 and $65^{\circ}$, with an increase in fractional lordosis in the caudal segments. ${ }^{6,7}$ The average global lumbar lordosis obtained by this study was around $52^{\circ}$ and the contribution of the L4 to S1 lordosis to total lumbar lordosis was $70 \%$. According to earlier reports,, 89 the last two mobile levels (L4-L5 and L5-S1) contribute around $60 \%$ of the global lumbar lordosis. The collapse of the segment underneath, due to degenerative disease, therefore results in significant decompression due to the large contribution of these discs to sagittal alignment. The results for total change in lumbar lordosis presented here did not undergo change post-arthrodesis. Through analysis of the distribution of lumbar lordosis among the levels, it was observed that prior to surgery - the period in which level L5-S1 was diagnosed as the principal cause of the clinical symptoms - the contribution of the segmental lordosis of L5S1 was similar to that of L4-L5, and the contribution from disc lordosis was even less. In the analysis of the 3-month period, these contributions increased to practically double those of L4-L5, which decreased in relation to the preoperative period.

The value of lumbosacral lordosis is affected by the type of fusion procedure chosen by the surgeon, and this must be taken into account when planning the surgery. Dimar et al. ${ }^{10}$ compared four arthrodesis techniques commonly used in the restoration of lumbar lordosis following single-level instrumented fusion: instrumented posterolateral fusion, transforaminal approach interbody fusion, anteroposterior fusion with posterior instrumentation, and anterior approach arthrodesis with lordotic cage. They discovered that the increase and maintenance of lordosis, and of the anterior and posterior height of the disc space, are better achieved with anterior arthrodesis using lordotic spacers. As with the technique, the form and the angulation of the interbody implants can also alter the sagittal alignment of the lumbar spine, as shown by other authors. ${ }^{11}$

The degeneration of the segment adjacent to a fusion is a multifactorial process. Besides the contribution of pre-existing changes and of the natural process of disc degeneration, sagittal alignment appears to make a significant contribution. In a case-control study, Djurasovic et al. ${ }^{2}$ studied possible predisposing factors for adjacent degeneration. They concluded that spinal fusion in abnormal sagittal alignment with loss of lumbar lordosis predisposes patients to the development of degeneration of the adjacent segment, ${ }^{2}$ a fact that can contribute significantly to an increase in the intradiscal pressure of the adjacent mobile segments, ${ }^{12}$ which, after fusion, have to work at the maximum limit of their functional movement more frequently. ${ }^{13}$ In addition to sagittal positioning, another factor that emerged in a systematic review of the literature ${ }^{3}$ as a potential protector of the adjacent level is fusion without the use of supplemental percutaneous screws, since these can damage the facet joints of the adjacent segment.

This study has some limitations to be considered. The group studied is relatively small, given that the very specific inclusion and exclusion criteria restricted the selection of a group with more patients. Moreover, not all the radiographs included the head of the femur, which made consideration of the pelvic incidence and pelvic rotation values impossible in those cases. 
Future studies are needed, to investigate whether restoration of the spinopelvic sagittal parameters of the adjacent levels can provide direct protection against the degenerative cascade.

\section{CONCLUSION}

In degenerative diseases of the isolated L5-S1 level, there is loss of segmental lordosis resulting in an increase in the angulation of the upper adjacent level. In the group studied, following anterior interbody fusion using lordotic spacers, it was possible to observe an increase in the lordosis of the level treated and a concomitant decrease in the lordosis of the adjacent mobile level.

Author Luiz Pimenta has conflicts of interest with MDT Implantes: consultant and intellectual property. The other authors have no relevant conflicts of interest.

\section{REFERENCES}

1. Vedantam R, Lenke LG, Keeney JA, Bridwell KH. Comparison of standing sagittal spinal alignment in asymptomatic adolescents and adults. Spine(Phila Pa 1976). 1998;23(2):211-5.

2. Djurasovic MO, Carreon LY, Glassman SD, Dimar JR 2nd, Puno RM, Johnson JR. Sagitta alignment as a risk factor for adjacent level degeneration: a case-control study. Orthopedics. 2008;31(6):546.

3. Park P, Garton HJ, Gala VC, Hoff JT, McGillicuddy JE. Adjacent segment disease after lumbar or lumbosacral fusion: review of the literature. Spine (Phila Pa 1976). 2004:29(17):1938-44.

4. Pfirrmann CW, Metzdorf A, Zanetti M, Hodler J, Boos N. Magnetic resonance classification of lumbar intervertebral disc degeneration. Spine (Phila Pa 1976). $2001 ; 26(17): 1873-8$

5. Modic MT, Steinberg PM, Ross JS, Masaryk TJ, Carter JR. Degenerative disk disease: assessment of changes in vertebral body marrow with MR imaging. Radiology. 1988;166(1 Pt 1):193-9.

6. Stagnara P, De Mauroy JC, Dran G, Gonon GP, Costanzo G, Dimnet J, et al. Reciprocal angulation of vertebral bodies in a sagittal plane: approach to references for the evaluation of kyphosis and lordosis. Spine (Phila Pa 1976). 1982;7(4):335-42.

7. Bernhardt M, Bridwell KH. Segmental analysis of the sagittal plane alignment of the normal thoracic and lumbar spines and thoracolumbar junction. Spine(Phila Pa 1976). $1989 ; 14(7): 717-21$

8. Gelb DE, Lenke LG, Bridwell KH, Blanke K, McEnery KW. An analysis of sagittal spinal alignment in 100 asymptomatic middle and older aged volunteers. Spine (Phila Pa 1976). 1995;20(12):1351-8.

9. Marty C, Boisaubert B, Descamps H, Montigny JP, Hecquet J, Legaye J, et al. The sagittal anatomy of the sacrum among young adults, infants, and spondylolisthesis patients. Eur Spine J. 2002;11(2):119-25

10. Dimar JR 2nd, Glassman SD, Vemuri VM, Esterberg JL, Howard JM, Carreon LY. Lumbar lordosis restoration following single-level instrumented fusion comparing 4 commonly used techniques. Orthopedics. 2011;34(11):e760-4.

11. Gödde S, Fritsch E, Dienst M, Kohn D. Influence of cage geometry on sagittal alignment in instrumented posterior lumbar interbody fusion. Spine (Phila Pa 1976). 2003;28(15):1693-9.

12. Weinhoffer SL, Guyer RD, Herbert M, Griffith SL. Intradiscal pressure measurements above an instrumented fusion. A cadaveric study. Spine (Phila Pa 1976). 1995:20(5):526-31

13. Chow DH, Luk KD, Evans JH, Leong JC. Effects of short anterior lumbar interbody fusion on biomechanics of neighboring unfused segments. Spine (Phila Pa 1976). 1996;21(5):549-55. 